\title{
Influence of Fluoride Concentration and pH Value of $35 \%$ Hydrogen Peroxide on the Hardness, Roughness and Morphology of Bovine Enamel
}

\author{
${ }^{1}$ Wilcilene Costa Nascimento, ${ }^{2}$ Yasmin do Socorro Batista de Lima Gomes, ${ }^{3}$ Larissa Dias Alexandrino \\ ${ }^{4}$ Hilton Tulio Costi, ${ }^{5}$ José Otávio Carrera Silva Jr, ${ }^{6} \mathrm{Cecy}$ Martins Silva
}

\begin{abstract}
Aim: The aim of this in vitro study was to evaluate the effects of different sodium fluoride ( $\mathrm{NaF}$ ) concentrations and $\mathrm{pH}$ values on the Knoop hardness (KHN), surface roughness (SR), and morphology of bovine incisors bleached with $35 \%$ hydrogen peroxide (HP).
\end{abstract}

Materials and methods: Sixty-five bovine incisors were fragmented $\left(5 \mathrm{~mm}^{2} \times 2 \mathrm{~mm}\right)$ and distributed in 5 groups: Control (unbleached), Low NaF/Acidic (35\% HP + 1.3\% NaF, pH 5.5), Low NaF/Neutral (35\% HP + 1.3\% NaF, pH 7.0), High NaF/ Acidic (35\% HP + 2\% NaF, pH 5.5), and High NaF/Neutral (35\% $\mathrm{HP}+2 \% \mathrm{NaF}, \mathrm{pH} 7.0)$. KHN analysis was performed with a microhardness tester under a load of $25 \mathrm{gf}$ for 5 seconds. The average SR was obtained with a rugosimeter. KHN and SR were analyzed before and after treatments. For morphological analysis, specimens were dehydrated and gold-sputtered, and scanning electron micrographs were obtained and analyzed by 3 examiners with a double-blinded technique. KHN and SR results were analyzed by one-way ANOVA and Tukey's test $(p<0.05)$.

Results: Only the Low NaF/Acidic and Low NaF/Neutral groups showed significant differences between the initial and final $\mathrm{KHN}$ values. All bleached groups presented significant differences between the initial and final SR values. Among the bleached groups, the least and most morphological changes were shown by the High NaF/Neutral and the Low NaF/Acidic group, respectively.

Conclusion: Treatment with $35 \% \mathrm{HP}$ and $2 \% \mathrm{NaF}$ at $\mathrm{pH} 7.0$ promoted the least changes in morphology, hardness and roughness among the bleached groups.

Clinical significance: In-office bleaching with high-concentration $\mathrm{HP}$ and $2 \% \mathrm{NaF}$ at neutral $\mathrm{pH}$ promoted the least changes in enamel hardness, SR, and morphology compared to other treatments.

\footnotetext{
${ }^{1-3}$ Undergraduate Student, ${ }^{4-6} \mathrm{PhD}$

1-3,6 Department of Dental Materials, Federal University of Pará, Pará, Brazil

${ }^{4}$ Department of Research, Museu Paraense Emílio Goeldi Pará, Brazil

${ }^{5}$ Department of Laboratory Pharmacotechnics, Federal University of Pará, Pará, Brazil
}

Corresponding Author: Cecy Martins Silva, Department of Dental Materials, Federal University of Pará, Pará, Brazil Phone: 559132521269, e-mail: cecymsilva@gmail.com
Keywords: Tooth whitening, pH, Fluoride, Hardness, Roughness, Hydrogen peroxide, Scanning electron microscopy.

How to cite this article: Nascimento WC, Gomes YSBL, Alexandrino LD, Costi HT, Silva JOC Jr, Silva CM. Influence of Fluoride Concentration and $\mathrm{pH}$ Value of $35 \%$ Hydrogen Peroxide on the Hardness, Roughness and Morphology of Bovine Enamel. J Contemp Dent Pract 2014;15(4):392-398.

Source of support: This article was supported by Institutional Program for Scientific Initiation and Technological Development and Innovation Federal University of Pará (PROPESP/PIBIC/ UFPA)

Conflict of interest: None declared

\section{INTRODUCTION}

Hydrogen peroxide (HP) is an effective bleaching agent for whitening teeth. ${ }^{1}$ When applied to the teeth, HP decomposes into unstable nonspecific free radicals, ${ }^{2}$ which break the large pigmented molecules in the enamel into smaller, lesspigmented molecules through a redox process. ${ }^{3}$ Studies have reported secondary clinical effects in the enamel hardness and morphology after peroxide exposure, ${ }^{4-7}$ at the enamel surface and subsurface levels. ${ }^{8,9}$ Although, high peroxide concentrations are not thought to cause macroscopic changes to the hard dental tissues, such increased porosity, depressions, or surface irregularities, ${ }^{10-12}$ researchers have reported increased roughness and reduced hardness with their use. ${ }^{13}$ The strong oxidizing effect of HP on the organic matrix of the teeth contributes to the enamel changes observed after bleaching.

The $\mathrm{pH}$ value of in-office whitening gels also plays an important role in the bleaching process and enamel changes. According to Pinto et $\mathrm{al}^{12}$ and Hegedüs et $\mathrm{al}^{14}$ changes to the dental structure are increased by a low $\mathrm{pH}$, which causes subsequent modifications to the mineral composition. Sun et al ${ }^{15}$ verified that although neutral and acidic $30 \%$ HP solutions had the same bleaching capacity, the acidic solution was more damaging to enamel. Demineralization of the enamel surface may be caused mainly by low $\mathrm{pH}$ and not by the action of the peroxide itself. ${ }^{16}$ Commercial bleaching agents have different $\mathrm{pH}$ values. Bleaching agents with high $\mathrm{HP}$ concentrations generally have an acidic $\mathrm{pH}$, favoring $\mathrm{HP}$ stability and facilitating the whitening process. ${ }^{17}$ Cadenaro et 
$\mathrm{al}^{18}$ reported that whitening agents with a low $\mathrm{pH}$ can cause softening of the hard dental tissue.

Some studies have shown that compared to nonfluoridated gels, fluoridated whitening gels tend to reduce the enamel's susceptibility to erosion/caries and to increase the whitened enamel's mineralization. ${ }^{19-22}$ Bistey et al ${ }^{6}$ observed a significant reduction in the fluoride content of enamel after HP bleaching. Adding fluoride to bleaching gels has been suggested to reduce the changes that occur in the enamel after whitening and to preserve the maximum resistance of the enamel. ${ }^{19}$ However, the optimal fluoride concentration to add to bleaching agents remains to be clarified.

The aim of this in vitro study was to evaluate the effects of different sodium fluoride $(\mathrm{NaF})$ concentrations and $\mathrm{pH}$ values on the Knoop hardness (KHN), surface roughness (SR), and morphology of bovine incisors bleached with $35 \%$ HP. We used bovine enamel for this study because of its similarity to human enamel in terms of hardness and composition. ${ }^{23,24}$ The null hypothesis was that the concentration of $\mathrm{NaF}$ and the $\mathrm{pH}$ of high-concentration $\mathrm{HP}$ would not promote changes in the hardness, roughness, or morphology of the enamel.

\section{MATERIALS AND METHODS}

\section{Specimen Preparation}

The study was approved by the Research Ethics Committee for Animal Experimentation of the Federal University of Pará (CEPAE-UFPA) as case $\mathrm{N}^{\circ} 110-13$. Sixty-five bovine incisors (Cooperativa da Indústria Pecuária do Pará LTDA, Maguari, Belém, Pará, Brazil) without cracks, stains, or any other defect to the enamel were used for this study. Each tooth was sectioned transversally on the crown/root edge across the amelocemental junction. The crowns were separated, and the roots were discarded. The vestibular surfaces were cut out with a double-sided steel disk (KG Sorensen, model 18002.7020, Cotia, Brazil) attached to a low-speed micromotor, under cooled water, to form fragments with an area of $25 \mathrm{~mm}^{2}$ and thickness of $2 \mathrm{~mm}$. The fragment dimensions were standardized and measured with a digital pachymeter. The cut-out portion always corresponded to the central area of the vestibular surface of the dental crown, so as to obtain enamel prisms with the same angles.

Surfaces of the specimens were planed with a polisher (APL-4 AROTEC Ltda, São Paulo, Brazil) by using wet sandpaper with granulations of 600, 1200 and 2000 (3M Brazil, Sumaré, Brazil). Samples used for KHN and SR analyses were planed and polished with a felt disk (Diamond Flex, FGM, Joinville, Brazil) attached to a micromotor, together with diamond polishing paste (Diamond Excel,
FGM, Joinville, Brazil). Specimens used for scanning electron microscopy (SEM) analyses were not planed; their surfaces were maintained whole.

\section{Experimental Groups}

Specimens were divided into groups according to the $\mathrm{NaF}$ concentration and $\mathrm{pH}$ value of the $35 \%$ HP used (Table 1). Each group contained 13 fragments, including 10 with planed and 3 with unplaned surfaces. The 10 planed fragments were used to analyze SR, with 5 of these also being used for the KHN test. The remaining 3 unplaned fragments from each group were used for SEM.

\section{Bleaching Procedure}

Bleaching agents were obtained from the A Fórmula pharmacy (Belém, Pará, Brazil) (Table 1). Three applications of bleaching agent were applied to the enamel for 15 minutes each, with an interval of 7 days between applications, over a 3 -week period. After each bleaching session, specimens were washed in running water. The surfaces were polished with a felt disk and diamond polish attached to a low-speed hand piece. The specimens were stored in artificial saliva (219 mg sodium bicarbonate, $12.5 \mathrm{mg}$ magnesium chloride, $82 \mathrm{mg}$ potassium chloride, $10 \mathrm{mg}$ nipasol, $0.8 \mathrm{mg}$ carboxymethyl, $127 \mathrm{mg}$ potassium phosphate, $44.1 \mathrm{mg}$ calcium chloride, $0.45 \mathrm{mg} \mathrm{NaF}, 2.4 \mathrm{mg}$ sorbitol and $100 \mathrm{ml}$ distilled water), which was replaced daily, in a biological incubator at $37^{\circ} \mathrm{C}$.

\section{Knoop Hardness}

Five specimens from each group were tested for KHN. Five indentations, separated by $100 \mu \mathrm{m}$, were made on each specimen by using a load of $25 \mathrm{gf}$ for 5 seconds in a microdurometer (FM-700, Future Tech Corp., Tokyo, Japan). Indentations were placed so that it was possible to map the whole area of the specimens (the left lateral, right, top, bottom, and central extremities). KHN was read before (initial) and immediately after (final) the bleaching treatment. The percentage of change in $\mathrm{KHN}(\% \mathrm{KHN})$ was calculated as: $\% \mathrm{KHN}=[($ Final $\mathrm{KHN}-$ Initial KHN $) /$ Initial KHN $] \times 100 \%$.

Table 1: Chemical components, concentration of sodium fluoride $(\% \mathrm{NaF})$, and $\mathrm{pH}$ of the bleaching agent in each group

\begin{tabular}{llll}
\hline $\begin{array}{l}\text { Groups } \\
(n=13)\end{array}$ & Chemical components & $\% \mathrm{NaF}$ & $\mathrm{pH}$ \\
\hline G1 & Controle (sem tratamento) & & \\
G2 & HP 35\%; carbopol 2.5\%; & 1.3 & 5.5 \\
G3 & methylparaben 0.2\%; & 1.3 & 7.0 \\
G4 & propylene glycol 0.15\%; & 2 & 5.5 \\
G5 & EDTA 0.1\%; distilled water & 2 & 7.0 \\
& qsp 100\% & & \\
\hline
\end{tabular}




\section{Surface Roughness}

Ten specimens were used for the SR reading. A rugosimeter (Surftest Mitutoyo Sul Americana Ltda, São Paulo, Brazil) was used to measure the SR before and after the whitening procedures. The point of the rugosimeter touched the specimen and explored the central $4 \mathrm{~mm}$, performing 3 diametrically opposite measurements. The average roughness superficial (average RS) was obtained, which had been previously established and calibrated using the machine's own program. The program compensated for (planar or convex) changes in the surface anatomy of the piece, without affecting the roughness results. The average RS is an arithmetic measurement of the roughness deviation profile that is obtained through the arithmetic average of the sum of the absolute values of the roughness deviation profile from the central line along the evaluated path. As a complementary analysis, the percentage change in SR (\%ARS) was calculated for each group, as shown in Graph 1 and according to the following formula: \%ARS $=[($ Final SR - Initial SR $) /$ Initial SR] $\times 100 \%$.

\section{Scanning Electron Microscope}

Three specimens from each group were dehydrated and goldsputtered with an EMITECH K550 metallizer. Metallization in this equipment was based on the interaction between a pure-gold target and argon ions (argon gas) at a pressure of $2.10^{-1}$ mbar and current of $25 \mathrm{~mA}$ for 2 minutes and 30 seconds, resulting in the deposit of a film with an average thickness of $\pm 15 \mathrm{~nm}$. Samples were mounted on aluminum supports of $10 \mathrm{~mm}$ in diameter (stubs) by using adhesive tape of carbon metalized with gold. Photomicrographs were obtained in a SEM (LEO, model 1450VP). Secondary electrons were detected at a voltage acceleration of $15 \mathrm{kV}$ and digitally recorded in high resolution, in a 'tiff' format. For

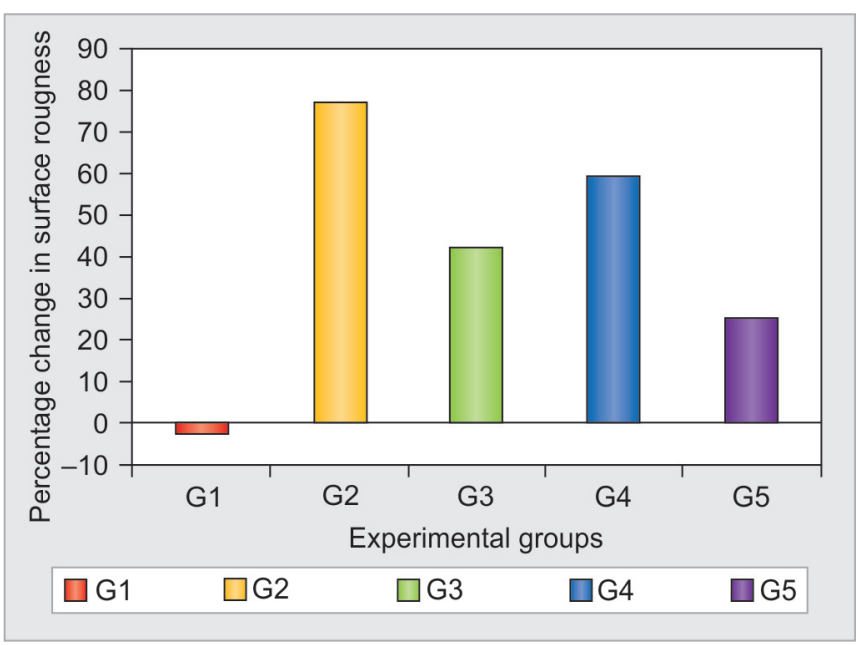

Graph 1: Percent change in average surface roughness after treatment the microstructural analysis, increases of 2000 and 6000 $\mathrm{Kx}$ were made, recorded and analyzed by 3 independent examiners using a double-blinded technique.

\section{Statistical Analysis}

To analyze the KHN and SR results, the BioEstat 5.0 statistical software was used. To analyze the statistical significance between the initial and final KHN and SR averages between the groups, one-way analysis of variance (ANOVA) and the Tukey test were used, with a 5\% significance level.

\section{RESULTS}

\section{Knoop Hardness}

Table 2 shows the between- and within-group comparisons for the $\mathrm{KHN}$ results. Initial $\mathrm{KHN}$ averages were similar in all groups. Groups with $1.3 \% \mathrm{NaF}$ (Low NaF/Acidic and Low $\mathrm{NaF} /$ Neutral) showed significant differences between the initial and final KHN averages. The Control group demonstrated the highest final KHN average among the groups. The final KHN average in the Low NaF/Neutral group was similar to those of all other bleached groups. The final KHN average of the Low NaF/Acidic group differed from those of the High $\mathrm{NaF} /$ Acidic and High $\mathrm{NaF} /$ Neutral groups, which were not significantly different from each other. The Control group showed a gain in \%KHN. The Low NaF/Acidic group had the highest \%KHN loss, followed by the Low NaF/ Neutral, High NaF/Acidic, and High NaF/Neutral groups, respectively (Graph 2).

\section{Surface Roughness}

Table 3 shows the comparisons between the initial and final SR averages. All of the groups showed similar initial SR averages and significant differences between the initial and final SR averages. The final SR averages for the bleached

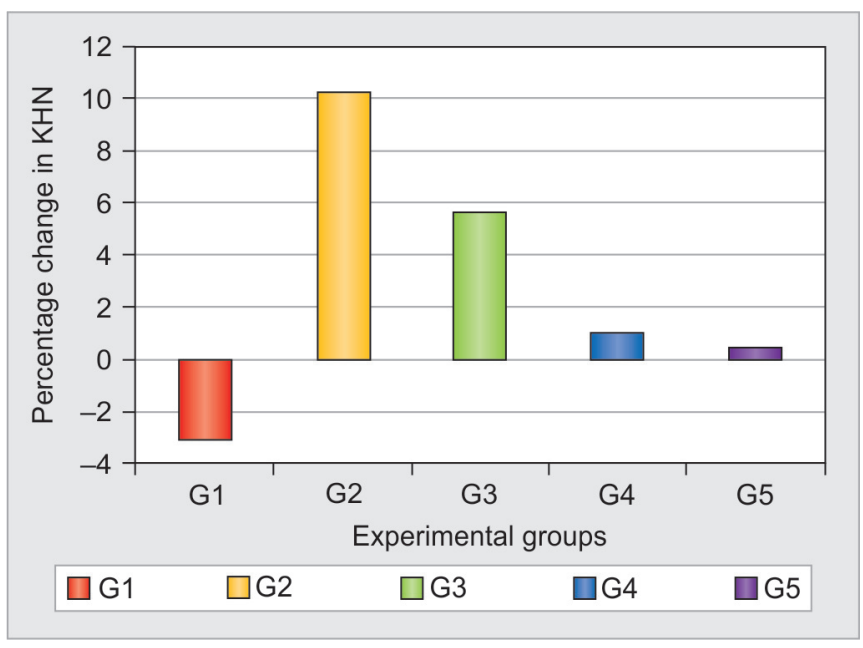

Graph 2: Percentage change in Knoop hardness $(\% \mathrm{KHN})$ after treatment 
Influence of Fluoride Concentration and $\mathrm{pH}$ Value of 35\% Hydrogen Peroxide

Table 2: Average (mean \pm SD) Knoop hardness values for each group before (initial) and after (final) treatment

\begin{tabular}{lll}
\hline $\begin{array}{l}\text { Groups } \\
n=5\end{array}$ & Initial & Final \\
\hline G1 (control) & $372.57 \pm 6.44^{\mathrm{Aa}}$ & $384.21 \pm 4.59^{\mathrm{Aa}}$ \\
G2 & $358.41 \pm 12.55^{\mathrm{Aa}}$ & $321.40 \pm 12.93^{\mathrm{Bb}}$ \\
G3 & $354.82 \pm 9.10^{\mathrm{Aa}}$ & $334.70 \pm 9.82^{\mathrm{BCb}}$ \\
G4 & $351.75 \pm 12.00^{\mathrm{Aa}}$ & $348.02 \pm 7.56^{\mathrm{Ca}}$ \\
G5 & $353.94 \pm 18.28^{\mathrm{Aa}}$ & $352.17 \pm 14.21^{\mathrm{Ca}}$ \\
\hline
\end{tabular}

*Groups with the same letter are statistically similar, capital letters on the vertical and lowercase letters on the horizontal

groups were significantly different from the final SR average of the Control group. There were no significant differences between the Low NaF/Neutral and High $\mathrm{NaF} / \mathrm{Neutral}$ groups, although they differed from the other groups.

\section{Morphological Analysis}

The enamel for the control group was smooth and whole (Fig. 1). In contrast, the bleached groups showed morphological changes, characterized by the partial removal of the aprismatic bed, depressions, porosities, and surface irregularities of different degrees of severity (Figs 2 to 5). Of the treated groups, the High $\mathrm{NaF} / \mathrm{Neutral}$ group showed the fewest morphological changes (Fig. 5).

\section{DISCUSSION}

Nonbleached control specimens stored in artificial saliva demonstrated an increased average KHN and decreased SR over time, consistent with the remineralizing effect of artificial saliva reported by Borges et al. ${ }^{25}$ All of the bleached groups showed reduced KHN and increased SR values of the enamel compared to the Control group, consistent with previous studies. ${ }^{8,12,14,26}$ Groups in which $2 \% \mathrm{NaF}$ was added to the bleaching agent had lower \%KHN, independent of their $\mathrm{pH}$ values. Therefore, we rejected the null hypothesis that the $\mathrm{NaF}$ concentration and $\mathrm{pH}$ value of high-concentration
Table 3: Average (mean \pm SD) surface roughness before (initial) and after (final) treatment for each group

\begin{tabular}{lll}
\hline Groups & Initial & Final \\
\hline G1 & $0.17 \pm 0.01^{\mathrm{Aa}}$ & $0.17 \pm 0.01^{\mathrm{Aa}}$ \\
$\mathrm{G} 2$ & $0.18 \pm 0.01^{\mathrm{Aa}}$ & $0.31 \pm 0.03^{\mathrm{Bb}}$ \\
$\mathrm{G} 3$ & $0.17 \pm 0.01^{\mathrm{Aa}}$ & $0.24 \pm 0.01^{\mathrm{Bc}}$ \\
G4 & $0.17 \pm 0.01^{\mathrm{Aa}}$ & $0.27 \pm 0.01^{\mathrm{Bd}}$ \\
G5 & $0.18 \pm 0.01^{\mathrm{Aa}}$ & $0.23 \pm 0.01^{\mathrm{Bc}}$ \\
\hline
\end{tabular}

*Groups with the same letter are statistically similar, capital letters on the vertical and lowercase letters on the horizontal

HP would not promote changes to the enamel hardness, roughness and morphology.

Previous studies have demonstrated that fluoride can promote remineralization in dental lesions, increase resistance to acid attacks, inhibit demineralization, and promote an increase in enamel hardness. ${ }^{26-31}$ One potential mechanism for these effects is that fluoride may contribute to the repair of microstructural defects through the absorption and precipitation of calcium and phosphate in saliva. ${ }^{32}$ In this study, the use of $2 \% \mathrm{NaF}$ with the bleaching agent minimized the decrease in $\mathrm{KHN}$ compared to $1.3 \% \mathrm{NaF}$, corroborating the findings of previous studies. ${ }^{26,31}$

Adding $2 \% \mathrm{NaF}$ to the whitening agent did not prevent the increase in SR in the High NaF/Acidic group. This result may have been due to the low $\mathrm{pH}(=5.5)$ of this group. Groups with neutral $\mathrm{pH}(=7.0)$ had less of an increase in SR compared to the control group, whereas the group with pH 5.5 and $1.3 \% \mathrm{NaF}$ demonstrated the greatest increase in SR. Borges et $\mathrm{al}^{25}$ reported that use of an acidic $35 \% \mathrm{HP}$ solution reduced the microhardness of the enamel compared to bleaching with $35 \% \mathrm{HP}$ with a neutral $\mathrm{pH}$, corroborating our results. Cadenaro et al ${ }^{18}$ performed an in situ study in which they evaluated the roughness caused by 2 in-office whitening agents, $38 \% \mathrm{HP}$ and $35 \%$ carbamide peroxide (CP). The use of $35 \% \mathrm{CP}$ did not change the SR of the enamel, presumably due to the neutral $\mathrm{pH}(=6.5)$ of $\mathrm{CP}$.
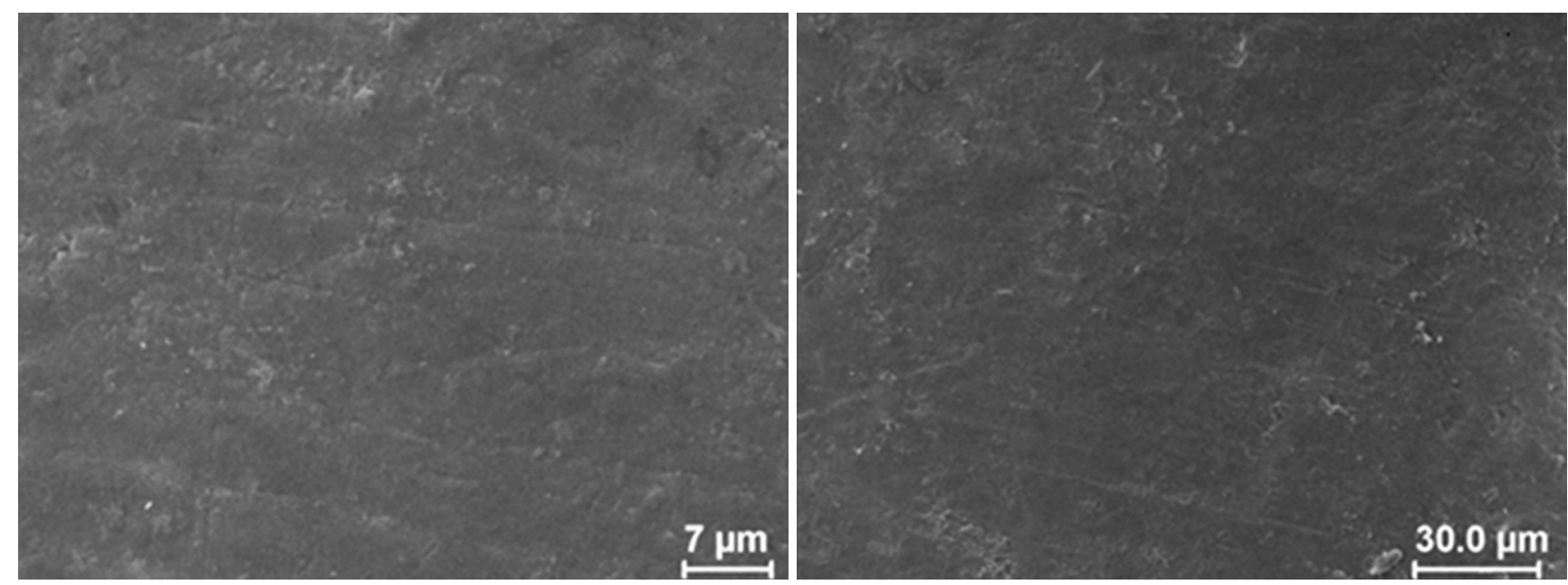

Fig. 1: Photomicrographs of untreated enamel, amplified 2000 and $4000 \mathrm{~K} \times$ 


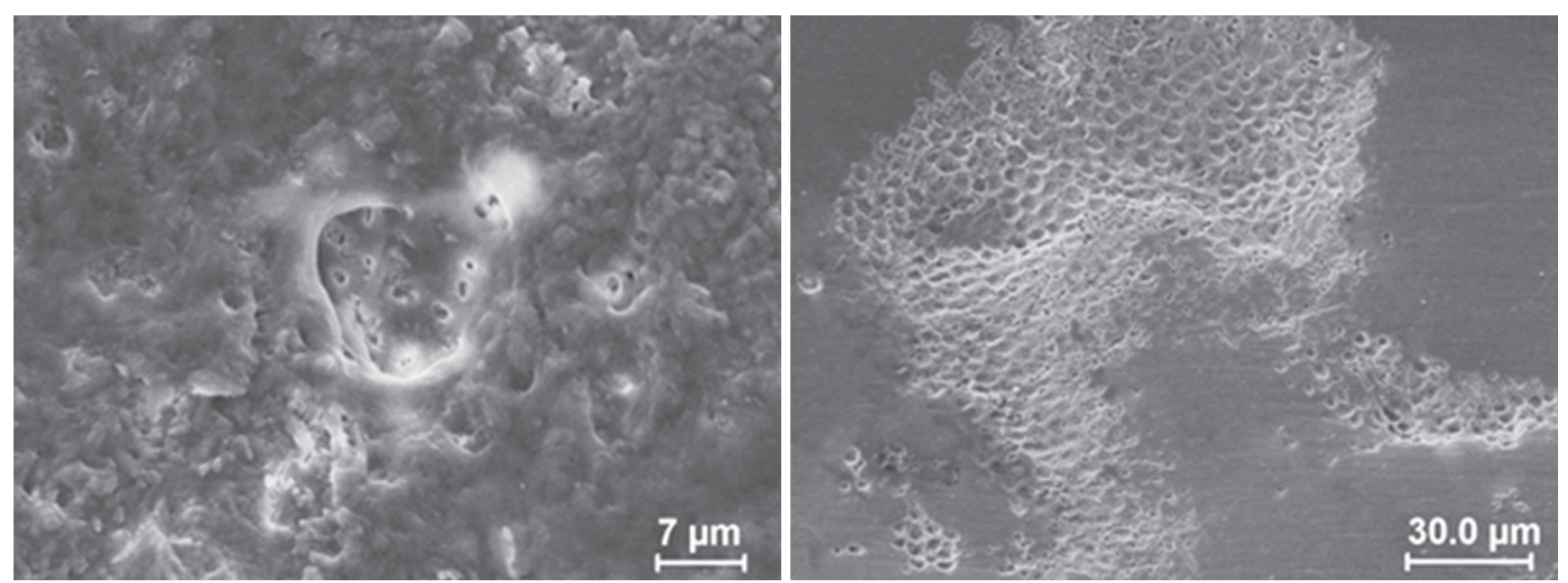

Fig. 2: Photomicrographs of enamel bleached with $35 \% \mathrm{HP}+1.3 \% \mathrm{NaF}$ at $7.0 "$

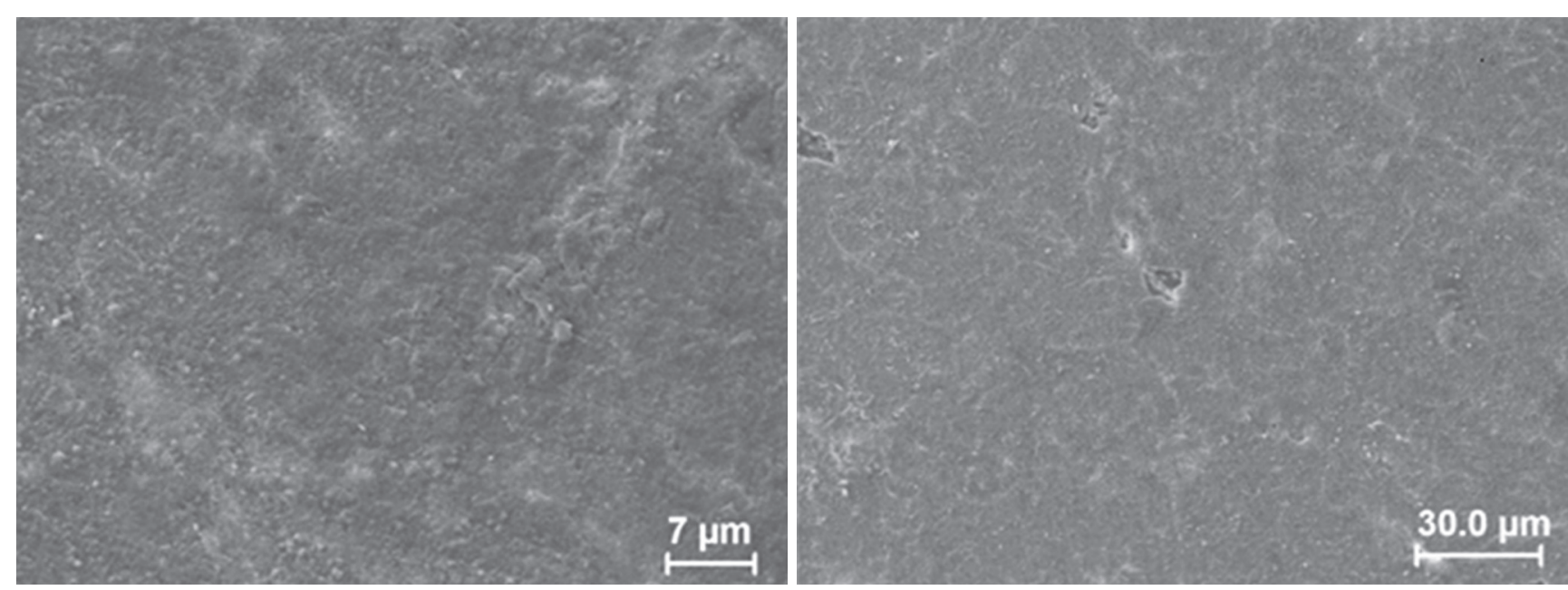

Fig. 3: Photomicrographs of enamel bleached with $35 \% \mathrm{HP}+1.3 \% \mathrm{NaF}$ at $\mathrm{pH} 7.0$
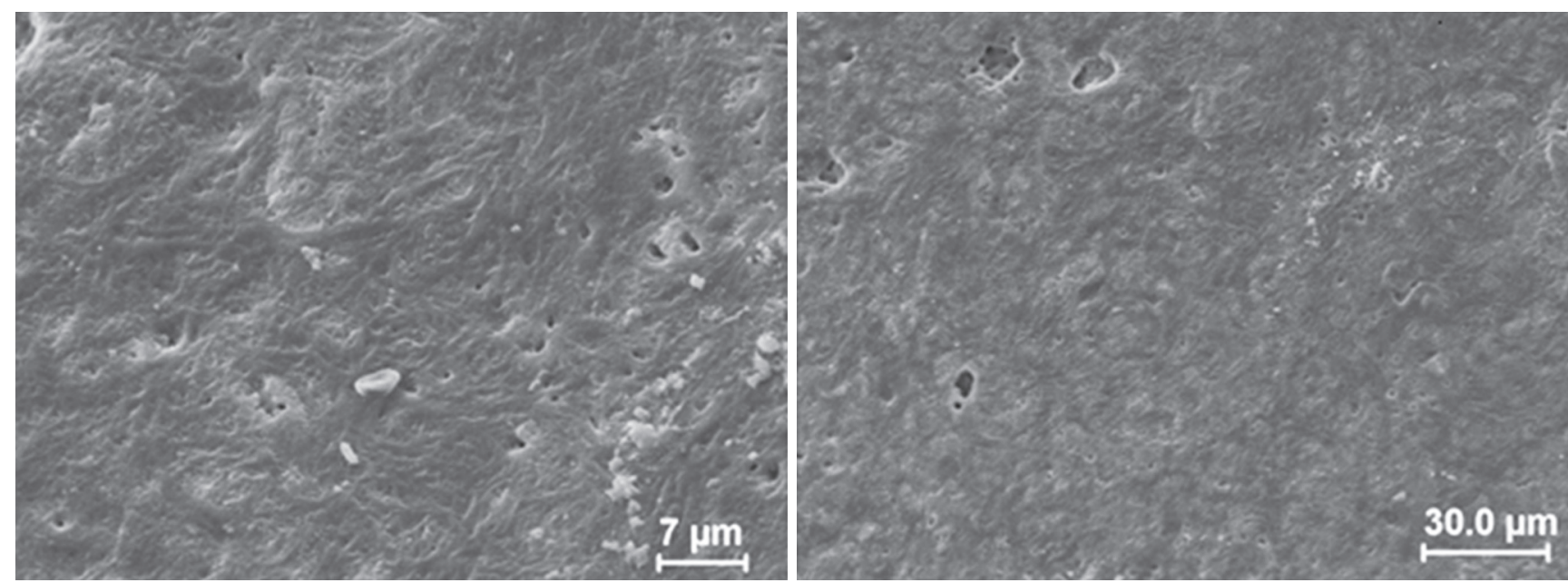

Fig. 4: Photomicrographs of enamel bleached with $35 \% \mathrm{HP}+2 \% \mathrm{NaF}$ at $\mathrm{pH} 5.5$

Previous studies have correlated the changes caused by bleaching with the $\mathrm{pH}$ of the bleaching agent. ${ }^{25,33-36}$ Price et $\mathrm{al}^{37}$ reported that higher concentrations of peroxide are associated with more acidic whitening products. Azrak et $\mathrm{al}^{38}$ showed that greater acidity of the bleaching agent was associated with greater damage to the hard dental tissue.
Among the bleached groups, we observed the least morphological changes in the group treated with $2 \% \mathrm{NaF}$ at $\mathrm{pH}$ 7.0. The greatest changes were displayed by the group with $1.3 \% \mathrm{NaF}$ and $\mathrm{pH} 5.5$, with partial removal of the aprismatic enamel bed, prism exposure and many porosities. The SEM results showed that the $\mathrm{NaF}$ concentration and $\mathrm{pH}$ of the $\mathrm{HP}$ 

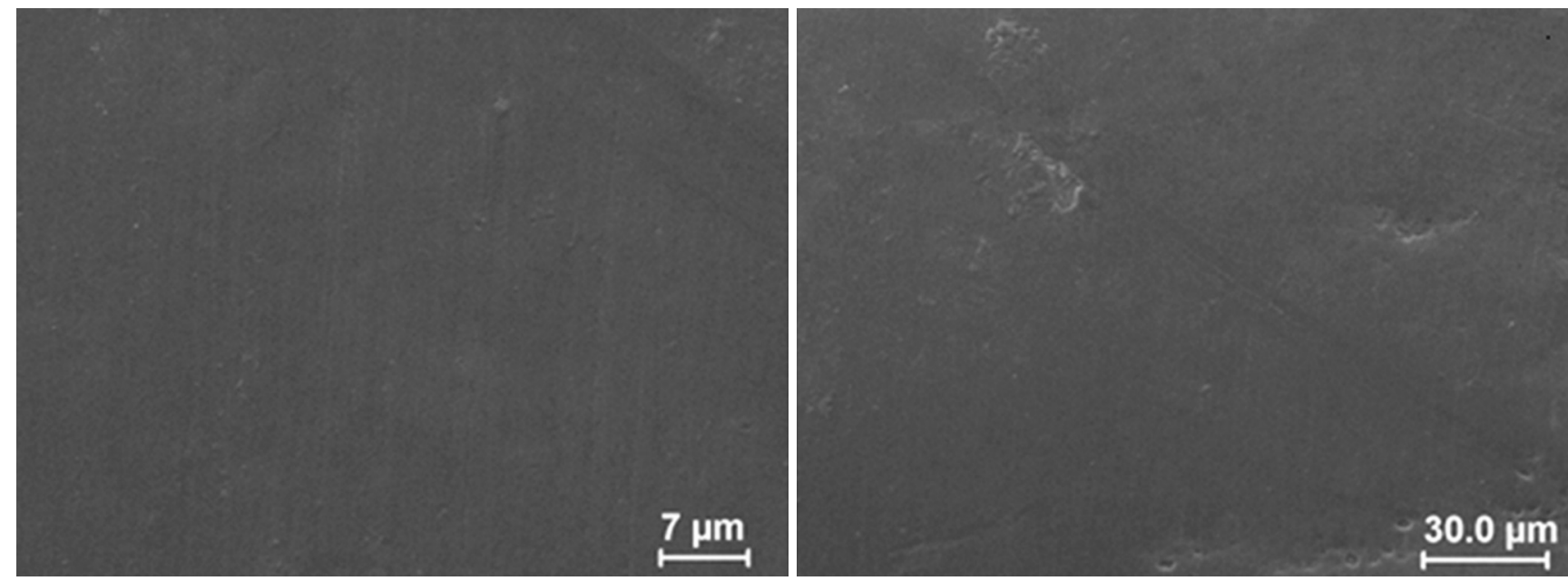

Fig. 5: Photomicrographs of enamel bleached with $35 \% \mathrm{HP}+2 \% \mathrm{NaF}$ at $\mathrm{pH} 7.0 "$

influenced the morphological pattern of the enamel, with a higher concentration of $\mathrm{NaF}$ and a neutral $\mathrm{pH}$ preventing demineralization and bleaching-related changes.

\section{CONCLUSION}

Based on the method used in this study, we can conclude that the use of $35 \% \mathrm{HP}$ with $2 \% \mathrm{NaF}$ at $\mathrm{pH} 7.0$ promoted the least change to the morphology and to the percentages of KHN and SR of the bovine enamel.

\section{CLINICAL SIGNIFICANCE}

In-office whitening with high-concentration HP with added $2 \% \mathrm{NaF}$ and a neutral $\mathrm{pH}$ promoted fewer changes to the hardness, roughness and morphology of bovine enamel.

\section{REFERENCES}

1. Heymann HO. Tooth whitening: facts and fallacies. Br Dent $\mathbf{J}$ 2005 Apr 23;198(8):514.

2. Kawamoto K, Tsujimoto Y. Effects of the hydroxyl radical and hydrogen peroxide on tooth bleaching. J Endod 2004;30(1): 45-50.

3. Tezel H, Ertaş OS, Ozata F, Dalgar H, Korkut ZO. Effect of bleaching agents on calcium loss from the enamel surface. Quintessence Int 2007;38(4):339-347.

4. Basting RT, Rodrigues AL Jr, Serra MC. The effect of $10 \%$ carbamide peroxide, carbopol and/or glycerin on enamel and dentin microhardness. Oper Dent 2005;30(5):608-616.

5. da Silva AP, de Oliveira R, Cavalli V, Arrais CA, Giannini M, de Carvalho RM. Effect of peroxide-based bleaching agents on enamel ultimate tensile strength. Oper Dent 2005;30(3):318-324.

6. Bistey T, Nagy IP, Simó A, Hegedus C. In vitro FT-IR study of the effects of hydrogen peroxide on superficial tooth enamel. J Dent 2007;35(4):325-330.

7. Carrasco-Guerisoli LD, Schiavoni RJ, Barroso JM, Guerisoli DM, Pécora JD, Fröner IC. Effect of different bleaching systems on the ultrastructure of bovine dentin. Dent Traumatol 2009;25 (2):176-180.

8. Akal N, Over H, Olmez A, Bodur H. Effects of carbamide peroxide containing bleaching agents on the morphology and subsurface hardness of enamel. J Clin Pediatr Dent 2001;25(4): 293-296.

9. Josey AL, Meyers IA, Romaniuk K, Symons AL. The effect of a vital bleaching technique on enamel surface morphology and the bonding of composite resin to enamel. J Oral Rehabil 1996; 23(4):244-250.

10. Ferreira Sda S, Araújo JL, Morhy ON, Tapety CM, Youssef MN, Sobral MA. The effect of fluoride therapies on the morphology of bleached human dental enamel. Microsc Res Tech 2011;74 (6):512-516.

11. Oltu U, Gürgan S. Effects of three concentrations of carbamide peroxide on the structure of enamel. J Oral Rehabil 2000;27(4): 332-340.

12. Pinto CF, Oliveira R, Cavalli V, Giannini M. Peroxide bleaching agent effects on enamel surface microhardness, roughness and morphology. Braz Oral Res 2004;18(4):306-311.

13. Borges AB, Samezima LY, Fonseca LP, Yui KC, Borges AL, Torres CR. Influence of potentially remineralizing agents on bleached enamel microhardness. Oper Dent 2009;34(5):593-597.

14. Hegedüs C, Bistey T, Flóra-Nagy E, Keszthelyi G, Jenei A. An atomic force microscopy study on the effect of bleaching agents on enamel surface. J Dent 1999;27(7):509-515.

15. Sun L, Liang S, Sa Y, Wang Z, Ma X, Jiang T, Wang Y. Surface alteration of human tooth enamel subjected to acidic and neutral 30\% hydrogen peroxide. J Dent 2011;39(10):686-692.

16. Sa Y, Chen D, Liu Y, Wen W, Xu M, Jiang T, Wang Y. Effects of two in-office bleaching agents with different $\mathrm{pH}$ values on enamel surface structure and color: an in situ vs. in vitro study. J Dent 2012;40 Suppl 1:e26-34.

17. Buchalla W, Attin T. External bleaching therapy with activation by heat, light or laser - a systematic review. Dent Mater 2007; 23(5):586-596.

18. Cadenaro M, Breschi L, Nucci C, Antoniolli F, Visintini E, Prati C, Matis BA, Di Lenarda R. Effect of two in-office whitening agents on the enamel surface in vivo: a morphological and noncontact profilometric study. Oper Dent 2008;33(2):127-134.

19. de Oliveira R, Paes Leme AF, Giannini M. Effect of a carbamide peroxide bleaching gel containing calcium or fluoride on human enamel surface microhardness. Braz Dent J 2005;16(2):103-106.

20. Lewinstein I, Fuhrer N, Churaru N, Cardash H. Effect of different peroxide bleaching regimens and subsequent fluoridation on the hardness of human enamel and dentin. J Prosthet Dent 2004; 92(4):337-342. 
21. Attin T, Kocabiyik M, Buchalla W, Hannig C, Becker K. Susceptibility of enamel surfaces to demineralization after application of fluoridated carbamide peroxide gels. Caries Res 2003;37(2):93-99.

22. Attin T, Betke H, Schippan F, Wiegand A. Potential of fluoridated carbamide peroxide gels to support post-bleaching enamel rehardening. J Dent 2007;35(9):755-759.

23. Urabe I, Nakajima S, Sano H, Tagami J. Physical properties of the dentin-enamel junction region. Am J Dent 2000 Jun;13(3): 129-135.

24. Mellberg JR. Hard-tissue substrates for evaluation of cariogenic and anti-cariogenic activity in situ. J Dent Res 1992;71:913-919.

25. Borges AB, Yui KC, D'Avila TC, Takahashi CL, Torres CR, Borges AL. Influence of remineralizing gels on bleached enamel microhardness in different time intervals. Oper Dent 2010;35(2): 180-186.

26. Cavalli V, Rodrigues LK, Paes-Leme AF, Soares LE, Martin AA, Berger SB, Giannini M. Effects of the addition of fluoride and calcium to low-concentrated carbamide peroxide agents on the enamel surface and subsurface. Photomed Laser Surg 2011; 29(5):319-325.

27. Chen HP, Chang CH, Liu JK, Chuang SF, Yang JY. Effect of fluoride containing bleaching agents on enamel surface properties. J Dent 2008;36(9):718-725.

28. Attin T, Kielbassa AM, Schwanenberg M, Hellwig E. Effect of fluoride treatment on remineralization of bleached enamel. J Oral Rehabil 1997;24(4):282-286.

29. White DJ, Featherstone JD. A longitudinal microhardness analysis of fluoride dentifrice effects on lesion progression in vitro. Caries Res 1987;21(6):502-512.
30. Cavalli V, Rodrigues LK, Paes-Leme AF, Brancalion ML, Arruda MA, Berger SB, Giannini M. Effects of bleaching agents containing fluoride and calcium on human enamel. Quintessence Int 2010;41(8):e157-165.

31. da Costa JB, Mazur RF. Effects of new formulas of bleaching gel and fluoride application on enamel microhardness: an in vitro study. Oper Dent 2007;32(6):589-594.

32. Pedreira De Freitas AC, Botta SB, Teixeira Fde S, Salvadori MC, Garone-Netto N. Effects of fluoride or nanohydroxiapatite on roughness and gloss of bleached teeth. Microsc Res Tech 2011; 74(12):1069-1075.

33. Miranda CB, Pagani C, Benetti AR, Matuda Fda S. Evaluation of the bleached human enamel by scanning electron microscopy. J Appl Oral Sci 2005;13(2):204-211.

34. Martin JM, de Almeida JB, Rosa EA, Soares P, Torno V, Rached RN, Mazur RF. Effect of fluoride therapies on the surface roughness of human enamel exposed to bleaching agents. Quintessence Int 2010;41(1):71-78.

35. Dominguez JA, Bittencourt B, Michel M, Sabino N, Gomes JC, Gomes OM. Ultrastructural evaluation of enamel after dental bleaching associated with fluoride. Microsc Res Tech 2012;75 (8):1093-1098.

36. Sulieman M, Addy M, Macdonald E, Rees JS. A safety study in vitro for the effects of an in-office bleaching system on the integrity of enamel and dentine. J Dent 2004;32(7):581-590.

37. Price RB, Sedarous M, Hiltz GS. The $\mathrm{pH}$ of tooth-whitening products. J Can Dent Assoc 2000;66(8):421-426.

38. Azrak B, Callaway A, Kurth P, Willershausen B. Influence of bleaching agents on surface roughness of sound or eroded dental enamel specimens. J Esthet Restor Dent 2010;22(6):391-399. 